\title{
CONCEPCION DEL LIBERTADOR AMERICANO EN UN POEMA DE P. NERUDA
}

\author{
Guillermo Barzuna Pérez *
}

El tema de la liberación americana, constituye uno de los signos más recurrentes de los escritores hispanoamericanos. A través de la historia del continente se presentan tres coyunturas relevantes en torno al problema de la liberación del pueblo americano: la conquista, la independencia y el siglo $\mathrm{XX}$. De la época de la conquista han quedado manifiestos de diversas culturas, tales como la azteca y la nahuatl, en las que se pone de relieve el dolor del indígena ante la invasión foránea.

De igual manera se encuentran documentos de los poetas y hombres que de una u otra manera se preocuparon por lograr la identidad y la reivindicación de derechos en los albores de la independencia. Representantes de todos estos países como Martí en Cuba, Bolívar en Venezuela, Esteban Echeverría en Argentina y otros, testimonian las letras del continente bajo el lema de la libertad.

En la época actual, basta mencionar el movimiento de la nueva novela a partir de los años sesenta; y de los poetas líricos. César Vallejo, Nicolás Guillén, Ernesto Cardenal, Jorge Debravo y Pablo Neruda, entre muchos otros, que han manifestado, a través de su escritura, un afán marcadamente emericanista.

En el presente estudio, interesa señalar la visión del libertador que se desprende de la lectura y enálisis del poema que introduce el libro "Los libertadores", poemario perteneciente al "Canto General" de Pablo Neruda. Los setenta poemas que componen el libro poseen un eje semántico común: la afirmación de la libertad; la cual se concreta en la imagen del árbol y por ende de la matenia terrestre como elemento metafórico de la libertad. (1)

Interesa destacar que el presente acercamiento

Profesor de Castellano. Escuela de Estudios Generales U. de C.R. Profesor de Lengua y Literatura. Centro de Estudios Generales U.N.A. se aborda desde una perspectiva semiológica. En este sentido, se considera el texto poético como una producción o mensaje artístico en que coexisten diversas funciones del signo.

Se hablará de función poética, $\Theta$ de la relación del mensaje consigo mismo, función determinante de todo mensaje artístico. De función emotiva o centrada sobre las posibilidades anímicas y expresivas del emisor lírico, así como de las relaciones que se establecen entre el sujeto hablante, y el mundo designado. De función conativa, o recursos dirigidos al receptor lírico; y de función referencial, que sería aquella que convoca al mundo de objetos, seres, e ideas, designados por el hablante.

En la función poética, interesa también señalar las posibilidades paradigmáticas y sintagmáticas, a las cuales recurre el emisor para elaborar y a la vez estructurar su discurso lírico. En este sentido el presente trabajo se preocupa por identificar en el texto los rasgos semánticos relevantes, así como la organización que de los mismos hace el hablante. Lo que interesa en última instancia es la búsqueda de un sentido, o significación del mundo a través de las imágenes desplegadas.

Otro aspecto y limitación a la vez, que habría que tomar en cuenta es lo referente a la descripción de las diferentes funciones antes mencionadas. El análisis de las mismas debe entenderse, como representativo de un universo o engranaje más amplio que el meramente lingüístico. Las diversas funciones convocan a su vez un código social o sistema de significación mayor que sería el contexto histórico latinoamericano.

El procedimiento seguido para la descripción del objeto es éste: Se parte de la linealidad del enunciado, por lo cual se fragmenta el discurso en diversos núcleos de significación que se desarrollan en torno a la imagen obsesiva del texto. A su vez estas unidades, serán objeto de reclasificación en Subunidades, tantas veces como lo requiere el despliegue significativo de las imágenes. En esta des- 
cripción siempre interesará la mostración de las diferentes funciones componentes del mensaje, así como su posible interdependencia. Por último interesará destacar la correlación entre los diversos componentes discursivos y el sintagma total.

Los libertadores: el título alude a una de las imágenes obsesivas. Y, por lo tanto, relevantes, en la significación del poema: la imagen "libertador", que aparece configurada en virtud del elemento terrestre "árbol". De lo anterior se derivará la fórmula metafórica: Libertador = "árbol", que se transforma en el elemento reiterativo de los diversos sintagmas componentes del discurso. (2)

\section{Versos $1 / 8$}

"Aquí viene el árbol, el árbol

de la tormenta, el árbol del pueblo

De la tierra suben sus héroes

como las hojas por la savia,

5 y el viento estrella los follajes

de muchedumbre rumorosa,

hasta que cae la semilla

del pan otra vez a la tierra". (3)

En el nivel semántico los paradigmas del campo asociativo señalan un punto de referencia: "la tierra", del cual se deriva un proceso de movilización de las imágenes. Este proceso conlleva una doble dirección, que se denomina de ascenso y descenso de los elementos metafóricos del discurso. La deixis adverbial "Aquî" indica la apertura del proceso y el sentido de cercanía espacial del hablante en relación con su universo lírico.

\section{Mostración del proceso:}

"árbol, árbol/ de la tormenta, el árbol del pueblo". (a)

(b)

(c)

"De la tierra/suben sus héroes/... y el viento

(a)

estrella los follajes/ hasta que cae la semilla/ del

pan otra vez a la tierra".

Los paradigmas señalados con la letra (a) indican el punto de partida del objeto lírico: la tierra; los paradigmas indicados con (b) implican un sentido ascendente respecto del elemento (a): "de la tormenta/suben sus héroes/viento estrella"; los paradigmas señalados con (c) indican descenso hacia la tierra dentro de la linealidad discursiva: "el árbol del pueblo/hasta que cae la semilla/del pan otra vez a la tierra". (4)

$\mathrm{L}$ as imágenes convocan esencialmente a los elementos tierra y aire, pero el primero de ellos adquiere mayor importancia.

En el nivel fónico los recursos utilizados por el hablante, muestran el proceso de ascenso y descenso a la tierra:

- la aliteración del fonema vibrante "r" es un indicador del movimiento que se quiere desplegar: “árbol/árbol/tormenta/árbol/tierra/héroe/estre1la/muchedumbre/rumorosa/otra/tierra".

- el encabalgamiento predomina en la mayoría de los versos: $1 / 2,3 / 4,5 / 6,7 / 8$.

- 1a reiteración del lexema obsesivo "árbol": "árbol/árbol de/el árbol del".

- los formantes verbales indican la relevancia del tiempo presente: "viene/suben/estrella/cae". En cuanto a las implicaciones sémicas, los verbos subir y caer, señalan concretamente el proceso de ascenso y descenso, descrito anteriormente.

La imagen inicial "árbol" a través de la linealidad discursiva adquiere otras manifestaciones o sustituciones paradigmáticas hasta constituir la imagen de implicación colectiva "pueblo" en el verso 2 , y las imágenes del mismo sentido, "muchedumbre rumorosa" y "héroes", en los versos 6 y 3 respectivamente.

Los paradigmas de la secuencia señalan una identidad del hombre libertador con el proceso de gestación del árbol. Una vez más se manifiesta la constante del hablante nerudiano de fundamentar el mundo lírico en lo terrestre, para luego darle cabida al espacio humano. El hombre aparece configurado por tres lexemas de carácter genérico "pueblo/Héroes/muchedumbre", lo cual en el plano paradigmático equivale a tres sustituciones semánticas del mismo paradigma.

\section{Versos 9/17.}

"Aqui viene el árbol, el árbol

10 nutrido por muertos desnudos, muertos azotados y heridos, muertos de rostros imposibles, empalados sobre una lanza, desmenuzados en la hoguera, 
15 decapitados por el hacha, descuartizados a caballo, crucificados en la iglesia”. (p. 73)

Esta estrofa, delimitada por el hablante lírico, atribuye una relación de contigüidad semántica y posicional con la estrofa anterior. La reiteración de los lexemas "aquí/viene/y árbol" con sus respectivas implicaciones sémicas en el verso 9 señala la continuidad del despliegue de imágenes en el discurso. Otro rasgo que conforma la relación de contigüidad con la estrofa precedente, lo constituye la similitud semántica del verso 8 , con el verso 9; el verso 8 finaliza con la imagen tierra y el verso 9 se abre con una imagen terrestre: "árbol".

Los paradigmas de los versos 10/17 sustituyen semánticamente a la imagen "pueblo" del verso 2 , lo que establece una relación de similitud semántica y posicional entre las dos estrofas.

La estructura posicional que se desprende de estos versos queda constituída por el formante con carácter de sujeto "árbol nutrido" y por una serie de formantes atribuídos al sujeto designado: "por muertos desnudos/muertos azotados y heridos,/muertos de rostros imposibles,/ empalados sobre una lanza/desmenuzados en la hoguera,/decapitados por el hacha/descuartizados a caballo/crucificados en la iglesia".

En esta estrofa predomina una visión de muerte, a diferencia de los versos $1 / 8$ donde predominan las imágenes vitales: "savia/muchedumbre/rumorosa/ semilla del pan". Los lexemas "desnudos/azotados/ heridos/ imposibles/empalados/lan$\mathrm{za} /$ desmenuzados/ hoguera/ decapitados/ hacha/ descuartizados/ crucificados", refuerzan la imagen de muerte introducida por la reiteración significativa de los versos $10 / 12$.

E1 formante verbal "viene" conlleva el mismo sentido que en los versos precedentes junto a la imagen del "árbol"; los dos son lexemas implicadores de movimiento y señalan el deseo del hablante de revivir, y por lo tanto de rescatar, al pueblo enterrado.

\section{Versos $18 / 28$}

"Aquí viene el “árbol, el árbol cuyas raíces están vivas,

20 sacó salitre del martirio, sus raíces comieron sangre, y extrajo lágrimas dél suelo: las elevó por sus ramajes, las repartió en su arquitectura.

25 Fueron flores invisibles, a veces flores, enterradas, otras veces iluminaron sus pétalos, como planetas". (p. 73)

El verso 18 introduce los elementos reiterativos presentes en los versos de apertura de las estrofas precedentes; con lo que se establece el respectivo sentido de similitudes posicionales y semánticas con los mismos.

El paradigma constituído por el verso $19 \mathrm{im}$ plica el desarrollo de la continuidad discursiva con las imágenes de los versos 9/17.

En los versos 18/19 el hablante expresa lo que se llama una imagen enunciado, de la cual dependen los restantes versos de la estrofa. Así, de la imagen del árbol en movimiento, se origina otra, "cuyas raíces están vivas". Esta imagen, que implica la vida desde el interior de la tierra, aparece en relación de contigüidad posicional y semántica con la linealidad discursiva; en tanto remite a las imágenes significantes de muerte: (versos 9/17).

El formante verbal que indica la experiencia temporal del hablante, aparece en presente: "están".

Los paradigmas de esta estrofa conforman una estructura significativa en la dirección espacial de las imágenes. Los versos 19/22 señalan un descenso del elemento "árbol”: “cuyas raíces están vivas/sacó salitre del martirio/sus raíces comieron sangre/y extrajo lágrimas del suelo". Los versos 23/25 indican un ascenso del mismo elemento: "las elevó por sus ramajes, las repartió en su arquitectura. /Fueron flores invisibles". El verso 26 remite de nuevo a una dirección de descenso: "a veces flores enterradas", y los versos 27/28 implican de nuevo un ascenso del objeto: "otras veces iluminaron/sus pétalos como planetas". (5)

Este esquema metafórico de las imágenes como agentes del movimiento, originadas en la materia terrestre, establece una similitud semántica con las estrofas anteriores, que configuran el mismo proceso.

Las imágenes que remiten al interior de la tierra, ("raíces/sacó salitre/extrajo lágrimas del suelo/flores enterradas") la definen como la guardadora del fundamento de la vida. Las cualidades inherentes a este espacio son dadas por los atributos "martirio/sangre/lágrimas"; lexemas que implican un sentido de dolor del objeto en su descenso de la tierra. 
En sentido general se puede afirmar que la estrofa tiene su apertura con la imagen tierra y su cierre con la convocación de una imagen referente al elemento aire: "planetas".

En relación con los formantes verbales, se presenta un cambio temporal que incide en la visión de mundo del hablante. El tono enunciativo de los versos 9/10 dependiente del formante verbal en presente "están", conlleva un cambio al asumir los versos 20/28 el pretérito indefinido ("sacó/comieron/extrajo/elevó/repartió/fueron/iluminaron"). Este carácter traslaticio del tiempo verbal repercute en la actitud anímica del hablante, quien pasa del sentido enunciativo de los primeros versos a un tono más bien evocador del objeto mostrado.

Versos 29/34

"Y el hombre recogió en las ramas

30 las corolas endurecidas, las entregó de mano en mano como magnolias o granadas $\mathrm{y}$ de pronto, abrieron la tierra, crecieron hasta las estrellas". (p. 73)

La estrofa se inicia con la conjunción coputaliva " $Y$ " que establece una relación de contigüidad con los versos anteriores: además esta conjunción introduce una imagen genérica: "el hombre", elemento humano que incide directamente en el instrumento que sirve de contacto con la tierra: "las manos" (6). Las formas verbales "recogió/entregó" y los lexemas de "mano en mano" implican la utilización de ese órgano; poseedor de un sentido de transmisión del objeto.

Los paradigmas: "las corolas endurecidas/... como magnolias o granadas" sustituyen las imágenes referentes a los versos 9/17; en ellos los formantes verbales señalan la apertura de un proceso de ascenso desde la tierra hasta el aire: "recogió/entregó/abrieron/crecieron". Asimismo los sustantivos indican una dirección ascendente del objeto: de "ramas" a "estrellas". El movimiento iniciado por las imágenes se refuerza a través de los encabalgamientos de los versos $31 / 32,32 / 34$ y de la aliteración del fonema " $r$ ": "hombre/recogió/ramas/corolas/endurecidas/entregó/granadas/pronto/abrieron/tierra/crecieron/estrellas".

Versos $35 / 42$

35 "Este es el árbol de los libres.

$\mathrm{El}$ árbol tierra, el árbol nube.

El árbol pan, el árbol flecha, el árbol puño, el árbol fuego.

Lo ahoga el agua tormentosa

40

de nuestra época nocturna,

pero su mástil balancea

el ruedo de su poderío (p. 74)

La deixis pronominal "Este", implica dos rasgos relevantes en la linealidad discursiva: - cercanía espacial del hablante hacia el objeto lírico y - una relación de contigüidad posicional y semántica con la estrofa anterior. El verso 35 parte de la configuración mostrada a través de las imágenes de los versos 29/34. El lexema "este" establece una similitud semántica con la deixis de matiz espacial "aquí" de los versos 1-9-18. El formante verbal en presente "es" confiere a la estrofa el mismo sentido de cercanía.

E1 paradigma "libres" sustituye posicional y semánticamente a los de los versos 9/34. La imagen de libertad conlleva, por lo tanto, el paso de todos los procesos de descenso y ascenso del árbol, con respecto de la tierra. De esta manera se concreta líricamente la imagen telúrica del libertador en relación con la imagen del árbol.

El paradigma "árbol de los libres" es sustituído por una enumeración de paradigmas significativos: "árbol tierra/árbol nube/árbol pan/árbol flecha/árbol puño/árbol fuego". Los elementos de estas metáforas bimembres convocan a la presencia de tres signos: la tierra, el aire y el fuego, dependientes a su vez del elemento tierra (árbol). Hay una implicación en las mismas, de movimiento ascendente de la tierra, ("tierra/pan/puño") hacia el aire, ("nube/flecha").

Los versos 39/40 unidos por el recurso de encabalgamiento, señalan la presencia del signo agua, como elemento de negación de lo desplegado anteriormente; el formante verbal "ahoga" complementa este sentido de negación introducido por el hablante. El paradigma "nuestra época nocturna" implica una consideración desde la perspectiva histórica presente del hablante por excelencia. El atributo "nocturno", aplicado al contexto del emisor lírico, señala una similitud semántica con la imagen de negación del verso 39; específicamente con el lexema "tormentoso".

El verso 41 introduce un marco de límite, mediante el cual se establece la continuidad de las imágenes positivas iniciadas en el verso 35 . 
Versos $43 / 59$

Otras veces, de nuevo caen las ramas rotas por la cólera, y una ceniza amenazante cubre su antigua majestad:

Así pasó desde otros tiempos, así salió de la agonía,

hasta que una mano secreta, unos brazos innumerables, el pueblo, guardó los fragmentos, escondió troncos invariables y sus labios eran las hojas del inmenso árbol repartido, diseminado en todas partes, caminando con sus raíces.

Este es el árbol, el árbol del pueblo, de todos los pueblos de la libertad, de la lucha”. (p. 74)

En el verso 43 se instaura un paralelismo con - imágenes anteriores, que indicaron descenso del uijejeto lírico en dirección con la tierra. Los formantes "otra vez/de nuevo" intensifican este sencilibo de simultaneidad con las imágenes precedenIest

El formante verbal "caer" indica explícitamente el sentido de descenso. Las imágenes "ramas rotas por la cólera/ceniza amenazante/cubre su antigua majestad" señalan un proceso de anulación Le lo configurado anteriormente en la imagen persistente del árbol.

El verso 47 implica un marco de límite, que se ceitera en el verso siguiente y que se cierra en el verso 49 con la preposición "hasta", formante que II su vez introduce la imagen de las "manos"; esta irnagen sustituye al paradigma "pueblo" en los versos 49/50: "una mano secreta/brazos innumerables". En el verso 51 se consolida la imagen "pueBlo" siempre en estrecha relación con el uso del órgano manos: "guardó los fragmentos/escondió troncos invariables" (7).

Los versos 53/56 introducen la imagen del árbol, que sustituye paradigmáticamente e integra directamente la imagen de pueblo con la imagen obsesiva del discurso. Al mismo tiempo los versos 47/59 establecen un sentido de ascenso en relación con los versos 43/46. Los formantes verbales de los versos 53/56 indican movilidad y proyección del objeto lírico: "árbol: repartido/diseminado/caminando". (8)

La deixis de cercanía establecida por el formante "aquí" de los versos anteriores, queda susti- tuída por el pronombre "este" del verso 57.

Las imágenes de los versos $57 / 59$, reiteran la persistencia del árbol en relación de contigüidad posicional y semántica con la imagen "pueblo". El verso 59 introduce dos paradigmas en estrecho vínculo semántico con las imágenes pueblo y árbol: "libertad y lucha". (9) (10).

\section{Versos $60 / 76$}

60 "Asómate a su cabellera: toca sus rayos renovados: Hunde la mano en las usinas donde su fruto palpitante; propaga su luz cada día.

65 Levanta esta tierra en tus manos, participa de este esplendor, toma tu pan y tu manzana, tu corazón y tu caballo

70 en el límite de sus hojas. Defiende el fin de sus corolas, comparte las noches hostiles, vigila el cielo de la aurora, respira la altura estrellada,

75 sosteniendo el árbol, el árbol que crece en medio de la tierra". (p. 74).

Las imágenes de los versos 60/76 parten de 1o enunciado en los versos 57/59: "árbol de todos los pueblos/de la libertad y de la lucha".

Con base en esta imagen generalizadora del objeto lírico, los versos 60/76 introducen la relevancia de la función conativa. Los formantes vervales en imperativo señalan la intencionalidad hacia el destinatario lírico; de parte del hablante: "asómate/ toca/ hunde/ propaga/ levante/ participa/toma/monta/defiende/comparte/vigila/respira". El hablante convoca al destinatario a que penetre y se identifique con el objeto. Los paradigmas en mostración, remiten esencialmente al signo tierra y a las cualidades de luz y de oscuridad. Cabe decir que las imágenes implican en su mayoría ascenso del objeto (11).

En lineas generales, se deriva un proceso metafórico mediante el cual el hombre en su condición de libertador, surge como un producto del proceso creador de la naturaleza.

La reiteración del lexema árbol y su configuración genérica a través de la imagen del pueblo, intensifican la relevancia del fundamento terrestre, atribuído por el hablante, al espacio humano. 


\section{NOTAS}

(1) VILLEGAS, Juan. Estructuras miticas y arquetipicas en el Canto General de Pablo Neruda. (Ed. Planeta, Barcelona, 1976) pp. 56-58.

(2) Esta fórmula metafórica otorga la categoría de antropoformización de la naturaleza.

(3) NERUdA, Pablo. Canto General I $\left(5^{\circ}\right.$ edición. Ed. Losada, Buenos Aiłes, 1971) pp. 73-74. Para evitar la repetición de citas, se colocará inmediatamente después de la cita correspondiente, el número de página de la presente edición.

(4) La imágen del "árbol" inicia el proceso de ascenso apuntado. En relación con la tierra implica un sentido ascendente con la misma. Se añade a esto la imagen del libertador que asciende a la tierra para volver de nuevo a la misma. Los paradigmas de esta secuencia se inician con un objeto que convoca a lo terrestre "árbol" y tiene su cierre con el lexema "tierra".

(5) La estructura matafórica "fueron flores invisibles / a veces flores enterradas", aclara el sentido que el hablante desea conferir a la presencia de la vida, la cual se gesta en las entrañas de la tierra, para ascender posteriormente a la superficie.

(6) La contiguidad posicional y semántica permanece a través de la persistencia del pretérito indefinido en las diferentes imágenes.

(7) Las manos se convierten en el elemento que resguarda la historia y el fundamento humano. Manos que trabajan y construyen el devenir histórico de América Latina.

(8) Sobresalen posicional y semánticamente las imágenes referentes al uso de los labios y de las manos: expresión oral y de trabajo; elementos esenciales del hombre en la búsqueda de su identidad y de su liberación.

(9) La reiteración de la imagen "pueblo/árbol" implica el fundamento telúrico que el hablante atribuye al espacio humano. Libertador y naturaleza aparecen en estrecho vínculo para lograr tal finalidad.

(10) Se universaliza la imagen del "árbol" al proyectarse a todos los pueblos. Se desprende una constante del emisor lírico nerudiano, quien establece imágenes genéricas, válidas para cualquier pueblo en circunstancias similares.

(11) Yurkievich, Saúl en Fundadores de la nueva poesía latinoamericana (Ed. Seix Barral, Barcelona, 1973, p. 169) afirma lo siguiente en torno a la imagen del árbol: "El árbol es no sólo un tema orquestado con persistencia a través de múltiples motivos: -espesura, el crecimiento portentoso, el arraigo, la ramificación, etc.; también, y lo que es más importante, constituye un modelo imaginativo, un mitema transferible a todos los órdenes de la realidad, tanto a la genealogía humana, como a la geología. . . Los libertadores de América son sucesivas ramas de un mismo árbol; en ellas se opera el ciclo de las transformaciones vegetales".

\section{BIBLIOGRAFIA}

B ARTHES, Roland y otros. La semiología (Ed. tiempo contemporáneo, Argentina 1972).

DUCROT, Oswald; TODOROV, Tzvetan. Diccionario enciclopédico de las ciencias del lenguaje. (Ed. Siglo XXI, Argentina, 1972).

EDELINE, Francis. Análisis estructural del texto poético. (Colección Planteos estructurales, Argentina, 1971).

FERRARESI, Alicia C. de. La relación yo - tú en la poesia de Pablo Neruda. (Revista Iberoamericana vol. $\left.39, \mathrm{~N}^{\circ} 82-83,1973\right)$.

FRANCESCATO, M. P. de. La circularidad en la poesía de Pablo Neruda. (Revista Iberoamericana vol. 39 , $N^{\circ} 82-83,1973$ ).

GUIRAUD, Pierre. La semántica (Ediciones F.C.E., México, 1971).
JAKOBSON, Roman. Ensayos de lingüistica General. (Ed. Seix Barral, Barcelona, 1975).

JAKOSON, Roman y otros. Semiología, afasia y discurso psicótico. (Ed. Rodolfo Alonso, Buenos Aires, 1973).

LE GUERNS, Michel. La metáfora y la metonimia. (Ed. Cátedra, Madrid, 1976).

NERUDA, Pablo. Canto General I. (Ed. Losada, Buenos Aires, 1971).

UL LMANN, Stephen. Semántica. (Ed. Aguilar, Madrid, 1976).

VILLEGAS, Juan. Estructuras miticas y arquetipicas en el Canto General de Pablo Neruda. (Ed. Planeta, Barcerlona, 1976).

YURKIEVICH, Saúl Fundadores de la nueva poesía latinoamericana. (Ed. Seix Barral, Barcelona, 1973). 